\title{
Rebranding a Federation: Insights from the UK Co-operative Movement
}

\author{
by \\ Eric Calderwood \\ And \\ Paul Freathy*
}

*Contact author

Institute for Retail Studies

University of Stirling

Stirling

FK9 4LA

e-mail: j.p.freathy@stirling.ac.uk

Tel: +44 1786467410

Fax +44 1786466290 


\section{Rebranding a Federation: Insights from the UK Co-operative Movement}

\section{Autobiographical Note}

Paul Freathy is Professor of Retail Management at the University of Stirling and Director of the Institute for Retail Studies

e-mail: j.p.freathy@stir.ac.uk

Tel: 01786467410

Eric Calderwood is a Group Board Director of the Co-operative Group and a part time lecturer at the Institute for Retail Studies, University of Stirling.

e-mail: eric.calderwood@stir.ac.uk

Tel: 01786467398

\section{Address for correspondence}

Institute for Retail Studies

University of Stirling

Stirling

Scotland

FK9 4LA 


\title{
Rebranding a Federation: Insights from the UK Co-operative Movement
}

\begin{abstract}
This paper details the rebranding process undertaken by the UK co-operative movement and provides an understanding of the strategic issues involved in maintaining a coherent brand identity across a group of autonomous independent societies. The methodology uses previously unpublished and archive material from across the movement. This is followed by a series of structured interviews with Board Directors, senior management and individuals responsible for implementing the rebranding strategy. The rebranding exercise took almost ten years and the research identifies nine (non discrete) overlapping stages. The paper argues that while many parallels with can be drawn with the corporate rebranding literature, the need to achieve compromise and consensus combined with the independence of those participating, creates issues not detailed in previous academic studies.
\end{abstract}

\section{Summary Statement of contribution:}

This paper attempts to make an original theoretical contribution to the academic literature by arguing that "Federal Rebranding" is a form of rebranding not identified or discussed in any previous study. Through case evidence, it illustrates the different stages involved in the rebranding process, details some of the practical difficulties and problems associated with undertaken such an exercise and may assist practitioners in future rebranding activities.

\section{Keywords:}

Rebranding

Retail

Co-operative Movement

Brands

The Co-operative Group

\section{Classification:}

Research Paper 


\section{Introduction}

'There is no point in hiding behind another name - we are the co-op, we should be proud of it and shout about it from the house tops. The new co-op symbol will have the merit of simplicity and directness. It will be sufficiently distinctive to indicate that it is new and will have built into it the factor of value and quality that should relate to the name co-op itself. The straightforward 'Co-op' mark will at once identify the product as being not just another C.W.S. product but as a society's own house brand.'

Source: Philip Thomas Chief Executive of the C.W.S. (Co-op News; $9^{\text {th }}$ September 1967).

Co-operatives are trading enterprises that are wholly owned and controlled by their membership ${ }^{\mathrm{i}}$. It is estimated that there are almost 5,500 such organisations in the UK with more than 12.8 million members and employing in excess of 236,000 people (Co-operatives UK, 2011). These enterprises range from small independent fish farms to the world's largest consumer cooperative, (The Co-operative Group (tCG)) who operate across a variety of market sectors (including retail, banking, travel and funeral care) (Co-operative Group, 2011). Despite its scope and scale, since 1945 the movement has experienced falling membership and a reduction in the number of organisations operating under co-operative principles ${ }^{\mathrm{ii}}$ (Walton 2009).

As will be illustrated, numerous reasons have been put forward to account for the decline of cooperatives as competitive trading enterprises, while at the same time a variety of solutions have been suggested that seek to reverse the fortunes of the movement. One (of the many) recommendations to be put forward has been the need to establish a distinct brand identity for the co-operative movement as a whole. This suggestion partially stems from the fact that it is a federal movement comprised of a series of independent, autonomous societies loosely bound together under a series of common values. While opportunities do exist to work together or share resources (for example, all UK food buying is centralised in one location), there remains 
no obligation on any society to participate or collaborate. While a number of previous attempts had been made to develop a coherent and consistent brand identity across the movement, overall these initiatives had met with only partial or limited success. This is despite significant academic research having identified that a discernible brand identity can offer companies distinct competitive benefits (Aaker 1996; Dias and Ryals 2002; Harris and de Chernatony, 2001; Urde 1999).

Between 2001 and 2009 the co-operative movement undertook a rebranding strategy that involved a holistic assessment of each element of its marketing and communications strategy. This extended beyond a simple re-badging exercise and store revamp programme to include a more fundamental evaluation of how the movement delivered its portfolio of products and services to the customer. In this sense, it involved a reconfiguration of many business processes and functions including a reassessment of its supply chain and merchandising operations.

The objective of this paper is two-fold. First, it will detail the rebranding process undertaken by the co-operative movement. This provides an understanding of the different tasks and activities involved in such an exercise. Through empirical research, the findings are able to categorise each activity into a series of (non-discrete, overlapping) stages. Secondly, having identified the process, the case evidence aims to contribute to the growing conceptual body of knowledge relating to rebranding. While reinforcing findings from previous studies, this paper provides an insight into the issues that arise when attempting to develop a unifying brand across a federal organisational structure. 
In so doing, this paper also helps rectify the identified lack of 'practice orientated' research into the study of marketing. It has been argued that an understanding of how marketing is actually undertaken in an organisation requires 'bottom up' empirical research and one that acknowledges the importance of human actors and their actions in marketing theory (Jarzabkowski and Spee 2009; Svensson 2007). As Järventie-Thesleff et al (2010) maintain, there is a need to move away from a focus upon the content and processes of strategy formulation towards an understanding of how brand strategies are managed within an organisation. A strategy in practice approach is predicated on the assumption that brand strategies are conducted by numerous practitioners and that empirically grounded research provides practical managerial guidance (Järventie-Thesleff et al 2010; Skålén, 2009; Skålén and Hackley, 2010). This paper will attempt to focus upon the actual praxis of rebranding and aim to illustrate that the human element is neither limited to the actions of senior management or the routines of practitioners (Jarzabkowski and Spee 2009; Skålén and Hackley, 2010).

\section{Literature Review}

A number of commentators maintain that the area of corporate rebranding remains well documented in the trade journals (Muzellec and Lambkin, 2006), but relatively under researched as an academic subject (Gotsi and Andriopoulos, 2007; Merrilees and Miller, 2008; 2011; Palmer 2004). Plewa et al (2011) argue that those studies that have been undertaken remain fragmentary and exploratory in nature. Moreover they estimate that under a dozen detailed scholarly studies of corporate rebranding have been undertaken which partly accounts for the limited theoretical base upon which these enquiries are founded. Despite this however, it has 
been argued that the concept of rebranding occupies a distinct conceptual position within the literature and that an understanding of the issues involved can make an important contribution to management practice (Gotsi and Andriopoulos, 2007).

While there may be broad agreement over the importance of rebranding, there remains less of a consensus over its actual definition. Some such as Merrilees and Miller (2008) define corporate rebranding as "..the disjunction or change between an initially formulated corporate brand and a new formulation.' (p. 538). They maintain that such an exercise typically requires a fundamental revision of the organisation's existing brand combined with a change management programme that elicits a shift in the cultural mindset of all staff.

Others such as Muzellec and Lambkin (2006) argue that the process of rebranding may not always require this form of 'revolutionary' change and the exercise may require a more 'evolutionary' approach. Evolutionary developments may be characterized as leading to fairly minor changes in the company's market position. Adjustments can be quite subtle and involve modifications to the brand or an amendment to an existing slogan. Some changes may be so slight that they are not appreciated or acknowledged by certain stakeholders. In contrast, 'revolutionary' rebranding represents a more radical change in the company's positioning and may be more akin to the process identified by Merrilees and Miller (2008). It may involve the creation of a new company name, new corporate brand vision or new brand values (see also Hatch and Schultz, 2003). However neither strategy is independent of the other and both are seen as being at either end of a continuum of change (Muzellec and Lambkin, 2006). 
What defines corporate rebranding is not just the scale of the exercise but where the change takes place. For example, Muzellec and Lambkin (2008) identify that a rebranding strategy may occur at one of three levels;

- Corporate Level - signifying change across the entire organisation;

- Strategic Business Unit Level - applying the principles of rebranding to a specific division or subsidiary within the organisation;

- $\quad$ Product Level -changes to the product brand name or specific product categories.

Gotsi and Andriopoulos (2007) maintain the majority of academic studies have been concerned with product and category change and while common issues can be identified across the different levels, a number of fundamental differences also exist. For example, it is maintained that corporate rebranding is more interdisciplinary in nature, ignores features specifically associated with the product and requires the organisation to be more explicitly featured in the process (Aaker and Joachimsthaler 2000). In order to realign an organisation's new strategic vision, close cooperation is required between a variety of departments and functions. Senior individuals may be tasked with managing the expectations of the multiple stakeholders affected and as a consequence, need to be much more sensitive to the wide spectrum of attitudes that may exist (Hankinson 2009; Merrilees and Miller 2008). This in turn may require a broader, more holistic communications strategy as traditional marketing methods cannot be relied upon to engender such fundamental change (Gotsi and Andriopoulos, 2007; Walter 2010).

At the corporate level, Muzellec and Lambkin (2006; 2009) further distinguish between a branded house strategy and a house of brands strategy. The former refers to a strategy where all divisions and subsidiaries are branded under a single corporate name, while the latter refers to a 
holding company with a collection of different brand names. For example, in the UK retail context, Tesco operates a portfolio of different formats under a single brand name (Tesco Extra, Tesco Superstore, Tesco Express, Tesco Homeplus, Tesco Metro). In contrast, the Kingfisher Group operate a number of separate strategic business units each with their own identifiable brand identity (B\&Q, Castorama, Brico Depot, Screw Fix, Koctas and Hornbach). Muzellec and Lambkin (2008) also note however that not all companies fit neatly into such categories and that an organisation's branding strategy often tends towards one approach or the other.

Rebranding is also acknowledged to be an expensive process that carries with it a high degree of reputation risk. For example, if an organisation embarks on a form of revolutionary rebranding that signals a fundamental shift in its market position, there remains the danger that the brand values and brand equity that have been created over many years, may be lost. (Muzellec and Lambkin 2006). This point is reiterated by Merrilees and Miller (2008) who note that while there is always pressure to ensure the contemporary relevance of the brand, all its previous values should not be abandoned if a rebranding exercise is undertaken. They maintain that such values are important in reaffirming the legacy and establishing the legitimacy of the new brand to customers.

Given the costs and potential risks involved in a corporate rebranding exercise, it is valid to examine under what circumstances such an activity may be undertaken. Gotsi and Andriopoulos (2007) note that rebranding may be seen as a natural step in an organisation's evolution and a necessary response to changing market circumstances. The requirement to sustain its contemporary relevance in the competitive marketplace acts as the primary driving force for a business. At the same time, Miller and Merrilees, (2011) note that a rebranding 
strategy may be triggered as a reaction to trading under-performance, acquisition and merger or in response to a declining, damaged or underperforming brand. For example, Lambkin and Muzellec's (2008 and 2011) studies illustrated how a rebranding strategy was used to rationalise and integrate a complex set of businesses that had been accumulated through acquisition. Although they noted that such an exercise can sometimes be considered as an afterthought, one outcome of the rebranding process was an increase in the overall brand equity of the organisation.

Once decided upon, a rebranding exercise requires careful planning as the process often involves a change to the organisation's cultural norms (Kapferer, 1997). For this reason, it is important to establish realistic timescales as a failure to address the temporal dimension can lead to failure in the rebranding process. While some maintain that a rebranding exercise can be performed overnight (Kaikati, 2003) other such as Gotsi and Andriopoulos (2007) maintain the process cannot be rushed and that sufficient time must be given in order to fully communicate and engage with stakeholders.

The more radical the rebranding, the higher the cost, the greater the degree of risk and the more time required in order to achieve the necessary transformations (Stuart and Muzellec, 2004; Gotsi and Andriopoulos, 2007). Gotsi et al (2008) in particular note the importance of strategically aligning the culture of the organisation with its espoused brand values and it remains important for a company to remain respectful of the internal values and assumptions that guide its behavioural norms. At the same time however they note the difficulties that belie the successful implementation of any cultural realignment programme. Not only is the company likely to face the prospect of competing organisational sub-cultures and individuals resistant to 
change, such transformations will often require changes in the attitudes and behaviour of staff members (see also Hankinson 2009; Vallaster and de Chernatony 2006).

While an organisation may approach the process of corporate rebranding in a number of different ways, Miller and Merrilees (2011) advocate a holistic approach that incorporates three phases.

- Phase 1: Re-visioning the Corporate Brand includes identifying the factors (or triggers) that led to the re-branding process.

- Phase 2: Achieving Stakeholder Buy-In to the Revised Corporate Brand focuses upon achieving buy in from both external as well as internal groups.

- Phase 3: Corporate Branding Strategy Implementation focuses upon managing the communication process and aligning the brand with its the operational and functional components (such as store design, displays and product packaging).

Against each of these phases Miller and Merrilees (2011) apply their previously constructed rebranding principles (Table One) and argue that Principles 1-3 are consistent with Phase 1 of the process, Principle 4 aligns with Phase 2 and finally Principles 5 and 6 are commensurate with Phase 3. 
Table 1: Principles and Phases of Corporate Rebranding

\begin{tabular}{|c|c|c|}
\hline Principle One & $\begin{array}{l}\text { A balance should be created between } \\
\text { the core ideology while at the same } \\
\text { time progressing the brand so it } \\
\text { remains contemporarily relevant. }\end{array}$ & \multirow{3}{*}{ Phase One } \\
\hline Principle Two & $\begin{array}{l}\text { Rebranding may require some core } \\
\text { concepts be retained as a bridge } \\
\text { between the old and revised brand }\end{array}$ & \\
\hline Principle Three & $\begin{array}{l}\text { Rebranding requires the organization } \\
\text { to meet the needs of new market } \\
\text { segments relative to supporting } \\
\text { existing segments }\end{array}$ & \\
\hline Principle Four & $\begin{array}{l}\text { Effective corporate rebranding requires } \\
\text { communication, training and internal } \\
\text { marketing }\end{array}$ & Phase Two \\
\hline Principle Five & $\begin{array}{l}\text { Each element of the marketing mix } \\
\text { needs to be aligned to the rebranding } \\
\text { strategy }\end{array}$ & \multirow[t]{2}{*}{ Phase Three } \\
\hline Principle Six & $\begin{array}{l}\text { Promotion is needed to make } \\
\text { stakeholders aware of the revised } \\
\text { brand. }\end{array}$ & \\
\hline
\end{tabular}

Source: abridged from Merrilees and Miller (2008; 2011) 
Table One is of particular value to this research as it helps identify the conceptual limitations of the current literature and the reasons why further theoretical development is required. Plewa et al (2011) maintain that the majority of academic research concentrates upon 'why' rebranding occurs rather than attempting to understand 'how' it manifests itself in practice. As a consequence, many case studies focus upon Phase One of the rebranding process and, while Phases Two and Three are acknowledged, the level of detail and discourse is often constrained. This in turn limits the opportunity to further conceptually develop the rebranding literature. For example, while Lambkin and Muzellec (2011) identify that rebranding can be used to integrate a complex set of businesses after acquisition, how this actually operates in practice is not examined. Similarly Miller and Merrilees (2011) comment upon the specific challenges of overcoming a declining brand when multiple stakeholders are involved. How consensus is reached in the absence of a single brand owner, how conflictual relationships are managed and the critical factors that determine a successful outcome are not addressed.

This paper attempts to partially rectify this acknowledged gap in the case literature by addressing all three of Miller and Merilees (2011) phases. The rebranding of the co-operative movement is detailed from the initial conceptualisation to the eventual roll out and, given its federal structure, the issues surrounding the management of multiple stakeholders will be examined. In so doing, the research will not only add to the limited 'practice orientated' rebranding literature, but should as Merilees and Miller's (2011:300) maintain, seek:

"... to reinforce this framework, modify it or replace it with a superior conceptualisation." 


\section{Context}

The historical development of the co-operative movement in the UK is well documented (Davis and Worthington,1993; Davies and Burt 2007) and has its origins in the need to protect consumers against exploitative food practices in the 1800s. Although co-operative retail societies were originally established to supply basic foodstuffs and distribute trading surpluses to its membership, the range of activities quickly grew to include wholesale redistribution, manufacture, shipping, banking and insurance (Wilkinson and Balmer 1996). While the principles of open membership, political neutrality and democratic control were unifying themes, societies traditionally remained independent of each other and were responsible for setting their own aims and objectives. Davies and Burt (2007) argue that while consumer co-operatives can be distinguished from market based organisations, the desire not to compete with other societies combined with a fragmented system of decision making and a focus upon local market outcomes have undermined their competitiveness and limited their growth (see also Hallsworth and Bell 2003).

Therefore, despite the movement in the United Kingdom having a combined turnover of $£ 33.2$ billion in 2010 (Co-operatives UK, 2011), it has continued to experience a decline in its trading performance since the latter half of the twentieth century (Birchall 2000; Davies and Burt 2007; Quinn and Sparks 2007; Sparks 1994). Not only has the period witnessed a fall in the movement's overall market share, many societies have been compelled to merge or face closure (Hallsworth and Bell, 2003). By 2010 there were only fourteen consumer co-operatives with an annual turnover of more than $£ 10$ million operating in the UK (Co-operatives UK, 2011). However not all societies have struggled in the competitive marketplace. The Co-operative Group (tCG), (formerly known as the CWS) is the world's largest consumer co-operative with 
operating profits of $£ 606$ million in 2010 (Co-operative Group, 2011). It employs over 110,000 people across a portfolio of businesses that include food, funerals, pharmacies, travel, farming, property, banking, insurance, legal services and online electrical. In 2009, tCG acquired the Somerfield food chain for $£ 1.6$ billion whilst also agreeing to mergers with the Britannia Building Society and the Plymouth and the South West Co-operative.

While linked under the broad category of being a co-operative, many societies continue to reflect their historical foundations and have emphasised their independence and autonomy from each other. For example, in the marketing arena many societies developed their own logos, fascias and promotional strategies and it was not until 1967 that the Co-operative Wholesale Society (C.W.S.), attempted for the first time to adopt a new umbrella symbol known as the 'cloverleaf' logo (Co-op News; 9 September 1967). The development of a single symbol was according to Thomas, designed to be 'applicable to all uses and applications' and formed part of an overall marketing strategy to 'improve the accepted image of the whole movement.' (Co-op News; 9 September 1967, p1). It was hoped that the independent co-operative societies would see the value of a centrally developed umbrella brand and consequently support its adoption. However success was limited with many societies choosing to resist what they considered to be a strategy imposed upon them and as the Report of the Co-operative Commission acknowledged over three decades later 'a number of core businesses are marketed without reference to the Co-op brand' (2001, p32).

The Co-operative Retail Trading Group (CRTG) was established by the CWS and three independent societies in 1993 to act as a centralised buying function for all member cooperatives. However it was not until 2002 that the last two independent societies applied for 
membership and, reflecting the autonomy that had underpinned their historical development, many of those trading under the Co-operative banner continued to use a variety of symbols to represent their businesses (Murphy 2004). These ranged from a wheat sheaf to a pair of clasped hands with little evidence to indicate any shared values or outlook between the different societies. This fragmented development has served to both limit and dilute the impact of its brand (Birchall 2000).

By the end of the twentieth century there was still no single Co-operative brand and senior members of various co-operative societies began voicing their concerns over the future of the movement and the need to halt the continuing decline in trading performance. It was at this stage that a co-operative delegation, including the Chief Executives of the CWS and the independent Oxford, Swindon and Gloucester Co-operative Societies approached the then Prime Minister, Tony Blair. The request was to set up a second Co-operative Commission, to undertake a fundamental review of the sector and propose ways to modernize and develop the movement in the $21^{\text {st }}$ century. As a result, Prime Minister Tony Blair, announced in 2000 that a Co-operative Commission would be established to take an independent evaluation of the sector. He noted:

'I am pleased to respond to your request to help set up and sponsor a Commission .... I agree with your desire to modernize the co-operative movement .. and to support your desire for a fundamental review' (quoted in Co-operative Commission Report p.10)

It was this review that signalled the start of the Co-operative rebranding exercise. 


\section{Methodology}

Brownlie and Saren (1997) identified the limitations of conventional representations of market management and noted how the rhetoric of managerial discourse gathered through empirical research, required careful scrutiny. They maintained that academics needed to move beyond the literal interpretation of the interview in order to fully explore organisational processes and work practices. Marketing researchers therefore need to engage in fieldwork that contextualises and triangulates the various narratives that are obtained. To respond to this and to fully detail the process of corporate rebranding a qualitative methodology, divided into three stages was deemed most appropriate (Eisenhardt, 1989).

During the first phase of secondary data collection, access was provided to internal documentation as well as archive material from the Co-operative Group and Co-operatives UK, (the trade association of the co-operative movement). In addition, permission was sought and granted to access the private records and minutes of a member of the actual Co-operative Commission.

The materials gathered at this stage of the research included presentations from senior Brand Managers, newsletters and numerous communications to management, staff and elected members, committee minutes as well as public relations articles. As part of the on-going attempt to communicate with stakeholders an exhibition had been erected in the Co-operative Group's head office. This detailed the reasons and rationale for the rebranding processes as well as well as highlighting the need for a coherent brand identity across the movement. Full access and copies of all exhibition material was made available to the researchers. The usefulness of 
secondary research in identifying emergent themes has been noted (Parker 2008) and the information provided at this stage helped facilitate the development of an appropriate line of enquiry.

The second phase of the research comprised a series of nine semi structured interviews with senior management and directors from across the co-operative movement. These individuals were selected on the basis of their active participation during key stages of the rebranding process. In order to provide a cross section of views, representatives were interviewed from independent societies, the Co-operative Group, the Co-operative Commission and the Brand Panel. Reflecting the structure of the co-operative movement many of those interviewed had occupied a variety of different roles during the period under study. This enabled them to comment upon more than one stage in the corporate rebranding process. Table Two highlights the respective responsibilities and involvement of interviewees in the rebranding process. 
Table 2: Interviewees for the second stage of the research

\begin{tabular}{|c|c|c|c|c|c|c|}
\hline & $\begin{array}{c}\text { Member of } \\
\text { Co-op } \\
\text { Commission }\end{array}$ & $\begin{array}{c}\text { Member of } \\
\text { Brand Panel }\end{array}$ & $\begin{array}{c}\text { CWS or Co- } \\
\text { operative } \\
\text { Group Director }\end{array}$ & $\begin{array}{c}\text { CWS or Co- } \\
\text { operative } \\
\text { Group Chair }\end{array}$ & $\begin{array}{c}\text { Independent } \\
\text { Society Chief } \\
\text { Executive }\end{array}$ & $\begin{array}{c}\text { Co-operative } \\
\text { Group } \\
\text { employee }\end{array}$ \\
\hline Interviewee 1 & $\checkmark$ & $\checkmark$ & $\checkmark$ & $\checkmark$ & $\checkmark$ & $\checkmark$ \\
\hline Interviewee 2 & $\checkmark$ & & $\checkmark$ & & & $\checkmark$ \\
\hline Interviewee 3 & & & & & & \\
\hline Interviewee 4 & & $\checkmark$ & $\checkmark$ & $\checkmark$ & & \\
\hline Interviewee 5 & & & $\checkmark$ & & $\checkmark$ & \\
\hline Interviewee 6 & & & $\checkmark$ & & & $\checkmark$ \\
\hline Interviewee 7 & & $\checkmark$ & $\checkmark$ & & & $\checkmark$ \\
\hline Interviewee 8 & & $\checkmark$ & & & & $\checkmark$ \\
\hline Interviewee 9 & & & $\checkmark$ & & & $\checkmark$ \\
\hline
\end{tabular}


During this phase, over 15 hours of qualitative research material was logged with the majority of interviews undertaken at tCG Head Office or at the interviewee's place of business. The length of the initial interviews ranged between 50 and 90 minutes. This number was deemed sufficient as by the end of the interviews recurrent themes and issues were being identified (Ahrens and Dent 1998; Strauss and Corbin 1988).

The final phase of the research involved a series of follow-up, qualitative, face-to-face interviews with individuals working across the co-operative movement. These included middle and senior management as well as democratically elected representatives drawn from Area Committees and Regional Boards. These interviews built upon the previous stage of the research and were primarily designed to answer specific strategic and operational aspects of the rebranding exercise (see also Provera et al 2010) which had been identified in the initial interviews and in so doing, confirm the accuracy of the information supplied. Individuals were chosen on the basis of their particular knowledge, responsibility or involvement in the process and, in a number of instances were recommended by interviewees from the second stage of the research. A total of 20 semi structured interviews were conducted in this phase of the research.

As the research sought to overcome some of the noted conceptual limitations identified in previous studies (Merillees and Miller 2011; Plewa et al 2011) all data were analysed using directed content analysis (Hsieh and Shannon, 2005). Using existing theories of rebranding, key concepts therefore provided the initial coding categories. Because respondents in Stage Two occupied a number of different roles, each individual was asked to narrate their own personal 
experiences and elaborate where necessary. Each interview was transcribed and initially read by both researchers. Both parties independently assigned the collected data to each of the predetermined categories and any data that could not be allocated was assigned a new category. These fragmented narratives were then used to construct an understanding of the rebranding process and obtain a sense of the 'whole' (Tesch 1990). As Lindebaum and Cassell (2012) note, through an iterative process of reading and re-reading the collected data, the aim of this approach is to take fragments of data and construct a storyline that provided a collective coherence. Such an approach is also consistent with the work of Currie and Brown (2003) and Ylijoki (2005).

Hsieh and Shannon (2005) note the possibility of creating bias in directed content analysis by assigning data to pre-existing categories rather than develop new, more appropriate groupings. To avoid this situation and ensure the accuracy of the collected data, the researchers went back to four individuals from the Stage Two interviews. These respondents were asked expand upon specific points raised in the initial interviews, reaffirm specific facts and confirm the accuracy of the information supplied. In addition, two of the interviewees were also asked to comment upon initial drafts of the paper.

While a qualitative approach to this form of investigation was considered most appropriate, there remain some noted limitations with the methodology employed. The ten year period over which the rebranding exercise took place meant that interviewees recollections of the early stages of the rebranding process were sometimes limited. While access to the secondary data partly ameliorated this situation, some details pertinent to the investigation are likely have been omitted. It is also acknowledged that a number of individuals were no longer connected with the 
co-operative movement. While the research attempted to interview persons directly involved in the rebranding process, some individuals remained untraceable or unavailable for comment.

\section{The rebranding process}

Attempting to develop a recognised and accepted corporate brand across a number of independent societies represents a significant and complex undertaking. To understand the primary strategic and operational issues that emerged, the following section first details the different stages involved in the co-operative rebranding process. The research identifies nine (non-discrete) stages of development and details briefly each phase from the establishment of the Co-operative Commission in 2000, through to the monitoring of the brand re-launch in 2009 (Table Three and Figure 1). The narrative from the empirical research then allows a discussion of the major challenges, obstacles and tensions that arose over the course of the rebranding exercise. By identifying these issues and considering the means by which they were resolved allows a series the key themes to be considered in the final section. 
Table 3: Stages in the Co-operative Rebranding Process

\begin{tabular}{|c|c|c|}
\hline Stage & & \\
\hline $\begin{array}{l}\text { Stage } \\
\text { One }\end{array}$ & $\begin{array}{l}\text { The Impetus for } \\
\text { Change }\end{array}$ & $\begin{array}{l}\text { The Co-operative Commission was established in February } 2000 \\
\text { with twelve members comprising senior business leaders, } \\
\text { politicians, trade unionists as well as representatives from the co- } \\
\text { operatives themselves }\end{array}$ \\
\hline \multirow[t]{2}{*}{$\begin{array}{l}\text { Stage } \\
\text { Two: }\end{array}$} & $\begin{array}{l}\text { The Creation of a } \\
\text { Brand Panel }\end{array}$ & $\begin{array}{l}\text { Composed of seven representatives from independent co- } \\
\text { operative societies, a representative from Co-operatives UK and } \\
\text { another from the non-retail co-operative sector. In addition there } \\
\text { were six representatives from the Co-operative Group including } \\
\text { a lay representative from the elected membership. }\end{array}$ \\
\hline & & $\begin{array}{l}\text { A Working Party was also formed to support the Brand Panel } \\
\text { and to oversee the development and management of the new } \\
\text { brand plus five 'Brand Standards Workstreams' to ensure } \\
\text { consistency of implementation across the different businesses. }\end{array}$ \\
\hline $\begin{array}{l}\text { Stage } \\
\text { Three: }\end{array}$ & $\begin{array}{l}\text { The Physical } \\
\text { Elements of the } \\
\text { Brand }\end{array}$ & $\begin{array}{l}\text { The translation of the brand model into tangible output. } \\
\text { Determining what the new Co-operative brand would look like, } \\
\text { how to communicate to stakeholders, and the standards that were } \\
\text { to accompany any re-launch. }\end{array}$ \\
\hline $\begin{array}{l}\text { Stage } \\
\text { Four }\end{array}$ & $\begin{array}{l}\text { Aligning } \\
\text { Operational } \\
\text { Standards }\end{array}$ & $\begin{array}{l}\text { Representatives from the largest societies in each business sector } \\
\text { along with key operations management from tCG are tasked with } \\
\text { developing 'best practice' in stores and outlets. Focus is upon } \\
\text { three areas customer experience; brand operating practices and } \\
\text { procedures and the customer offer. }\end{array}$ \\
\hline $\begin{array}{l}\text { Stage } \\
\text { Five: }\end{array}$ & Brand Pilot Tests & $\begin{array}{l}\text { The new Co-operative brand is tested across a representative } \\
\text { sample of locations, businesses and societies. A Brand Pilot } \\
\text { assesses change against a series of key criteria and helps } \\
\text { determines whether the brand could be successfully implemented } \\
\text { across all societies and business sectors within the Co-operative } \\
\text { movement. }\end{array}$ \\
\hline $\begin{array}{l}\text { Stage } \\
\text { Six }\end{array}$ & $\begin{array}{l}\text { Assessing Brand } \\
\text { Pilot Outcomes }\end{array}$ & $\begin{array}{l}\text { The Pilot stores and branches are compared against a control } \\
\text { group of stores as well as a range of financial and non financial } \\
\text { criteria. }\end{array}$ \\
\hline $\begin{array}{l}\text { Stage } \\
\text { Seven }\end{array}$ & $\begin{array}{l}\text { Preparation for } \\
\text { Brand Re-launch }\end{array}$ & $\begin{array}{l}\text { The process of changing all of business units to the new brand, } \\
\text { refurbishing stores and repackaging and re-launching own brand } \\
\text { products. }\end{array}$ \\
\hline $\begin{array}{l}\text { Stage } \\
\text { Eight }\end{array}$ & Brand Launch & $\begin{array}{l}\text { An integrated communications campaign that utilised a broad } \\
\text { range of conventional media including press, cinema and } \\
\text { billboards, direct marketing and point of sale material in all co- } \\
\text { operative stores and businesses as well as online and social } \\
\text { media. }\end{array}$ \\
\hline $\begin{array}{l}\text { Stage } \\
\text { Nine }\end{array}$ & $\begin{array}{l}\text { Post Launch } \\
\text { Performance }\end{array}$ & $\begin{array}{l}\text { An evaluation of the rebranding exercise against a series of } \\
\text { performance indicators, including sales, new members and } \\
\text { customer footfall. }\end{array}$ \\
\hline
\end{tabular}

Source: Authors Research 
Figure 1: Timelines for the Rebranding Process

Stage

2000

2001

2002

2003

2004

2005

2006

2007

1 Impetus for change

2 Creation of a Brand Panel

3 Physical elements of the Brand

4 Aligning Operational Standards

5 Brand Pilot Tests

6 Assessing Brand Pilot Outcomes

7 Preparation for Brand Re-launch

8 Brand Re-launch

9 Post Launch Performance
Commission Report Published 2001

Established 2002 Panel Continues to meet to address issues

Brand Working Panel

\section{Brand Workstreams}

Sept. 2005 - Sept 2006

Jan 2006 - Dec 2007

Board Approval July 2006

Launch 2009

Evaluation begins immediately upon launch 


\section{Stage One: The Impetus for Change}

One of the primary motivations for the rebranding exercise was the realisation amongst many members that the movement was underperforming and as a consequence, vulnerable to competitive pressures. As one member of the Co-operative Commission noted:

'The call for such a complete review worked in 2001 because there were far fewer societies (there were 932 societies in 1958) and the CWS was now the largest retailer. However, a number of senior people in the independent societies also saw the need for change. There was a realisation in the larger societies that something had to happen to deal with the spiral of decline. There was a need for strategic vision for the movement to move ahead. The threat of demutualisation helped to focus their minds. There was a realisation that a successful, engaged business was less threatened... The movement was not seen to be a modern organisation.'

After sitting for less than a year, the Report of the Commission was published in January 2001 with 60 separate recommendations on subjects ranging from recruitment to lifelong learning (Cooperative Commission 2001). The Report also made a number of key proposals concerning the rejuvenation of the Co-operative brand and the creation of a shared identity in order to improve the movement's commercial performance (Recommendations 16 -21).

Crucially, the Report recommended that a 'Co-operative Brand Panel should be established to develop a common national Co-operative branding approach for the Movement' (Recommendation 17.1).

One CEO of an independent society and former Group Chair noted the importance of the Commission's Report. It was seen to play an important legitimising role and added to the argument that a more 'business like' approach was required. As he identified: 
'The Commission's Report tipped the scales and made it easier for those who wanted a national brand'

However it was also added that the legitimacy of the Brand Project had been founded upon:

'very extensive research to ensure that this would be based upon the wants of the customer and not the likes and dislikes of any individuals (or the wants of individual societies).'

By defining the scale of the exercise and embedding this in empirical research helped manage the multiple stakeholders involved in the process and assisted with early decision making. For example, questions were initially raised as to whether other enterprises such as worker or agricultural co-operatives should be included. The subsequent decision not to include them was based in part upon findings that highlighted the complexity of rebranding across so many sectors and individual businesses.

\section{Stage Two: The Creation of a Brand Panel}

The development of a corporate brand capable of meeting the needs and expectations of a wide range of stakeholders required members of the Brand Panel to mirror the Commission's Report and transcend their personal interests and those of their own organisation.

Although the Commission had attempted to define the parameters of the rebranding exercise the research revealed that there still remained some uncertainty about the scope of the 'brand project', with different people assigning different interpretations to the Report. In particular, in 
the early stages views ranged from relatively modest (evolutionary) changes (such as 'tweaks to the cloverleaf logo or a new shop fascia) to a more fundamental (revolutionary) regeneration of the brand.

These seemingly polarised opinions were partly mediated and resolved through empirical research. As one Brand Panel member noted:

'It was the weight of research that stopped any arguments during this time. There was an analytical approach. The research showed that the Cloverleaf logo was disliked. This was not a startling discovery to some, as earlier research 5 or 6 years before had shown that the cloverleaf was not well perceived. Nevertheless, the process adopted helped the Brand Panel to make difficult decisions. It allowed them to move step by step towards a common desire for an overarching brand.'

The objective was to differentiate the Co-operative from the competition by creating a distinctive set of brand components designed to become the pillars upon which the business would be built and help establish a vision for the brand (Table Four). One respondent noted the importance of compromise during this stage of the process and the need to 'keep the bigger picture in mind'. For example, when one society objected to the use of the term Dividend (an identifiable term amongst co-operative members) the component was toned down to Rewarding. 
Table 4: Co-operative Brand Components

\begin{tabular}{|l|l|}
\hline Championing & $\begin{array}{l}\text { A Co-operative business makes things better for its } \\
\text { customers by creating, pioneering and implementing } \\
\text { innovative and socially responsible ideas that lead its } \\
\text { industry. }\end{array}$ \\
\hline Community & $\begin{array}{l}\text { A Co-operative business builds a close relationship with its } \\
\text { customers by being there for them, reflecting their needs and } \\
\text { contributing to their community. }\end{array}$ \\
\hline Rewarding & $\begin{array}{l}\text { A Co-operative business offers a welcoming, pleasing and } \\
\text { rewarding experience. It does something worthwhile with its } \\
\text { profits, leaving customers feeling they've well by both } \\
\text { themselves and others. }\end{array}$ \\
\hline Trustworthy & $\begin{array}{l}\text { A Co-operative business is honest, open and fair with its } \\
\text { customers, behaving with integrity at all times, and being } \\
\text { expert and accountable at what it does. }\end{array}$ \\
\hline $\begin{array}{l}\text { Consistent } \\
\text { quality }\end{array}$ & $\begin{array}{l}\text { A Co-operative business gives its customers good quality } \\
\text { products and great service at a fair price, wherever and } \\
\text { whenever they use it. }\end{array}$ \\
\hline
\end{tabular}

Source: The Co-operative Exhibition (2009) 
Once the components of the brand were agreed, they were distilled down to provide a single statement of what the brand offered - a brand proposition. This was the core message that needed to be consistent across all businesses and was designed to appeal to both new and potential customers. The Brand Proposition that the panel adopted was: 'Successful business with integrity'.

Once the brand proposition was agreed, the 'personality of the brand' or those characteristics which could be used to describe the brand to both customers and staff could be determined. The traits that the Panel decided upon were: open, decent, ambitious, friendly, healthy and cooperative. Finally, a decision was made on the 'brand essence', this provided a single thought that was deemed to be at the core of the brand. The Panel decided upon - Changing business for good. Figure One details how these elements were combined into a Co-operative Brand Model. 
Figure 2. The Co-operative Brand Model

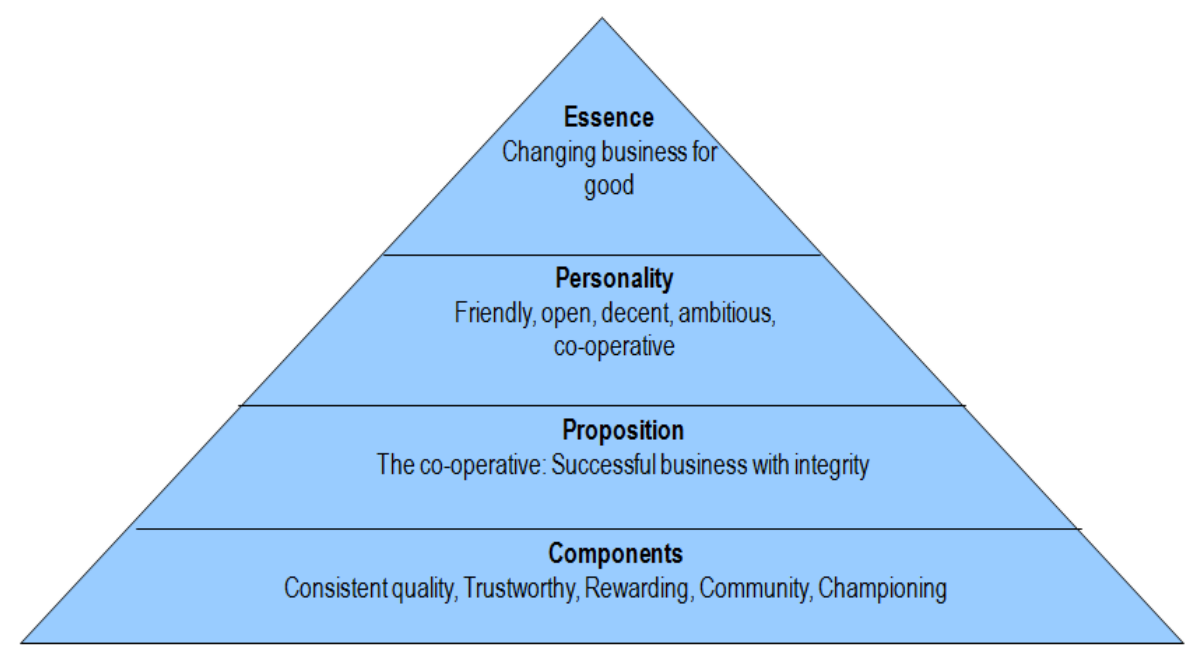

Source: The Co-operative Brand Experience Exhibition 2009 


\section{Stage Three: The Physical Elements of the Brand}

As noted previously, the co-operative movement had never fully embraced a single brand identity. Consequently any attempt to create something acceptable to all societies and across all businesses was unlikely to be straight forward. As a way of helping to overcome the anticipated resistance, the Brand Panel commissioned further research into perceptions of the brand as well as consulting widely with stakeholders.

The results identified that whilst consumers found 'The Co-op' to elicit connotations of 'packaged groceries' and 'limp lettuce', the name 'The Co-operative' was seen to leverage on the movement's heritage and traditional values. Using 'The Co-operative' as the brand identity was therefore seen to provide a positive statement of intent as it represented the movement's way of doing business. It was at this stage, that the decision was made to finally abandon the cloverleaf logo, develop a new corporate colour scheme and adopt the 'Co-operative' name as the master brand.

Some members of the Brand Panel expressed reservations with this strategy, maintaining instead that improvements could still be made to the existing designs. One member of the Brand Management team highlighted the dilemma that was felt at the time:

The 'cloverleaf' was thought to be a unifying symbol but it was primarily used in food stores and very little elsewhere. '..... It was being used during the 1990s in the businesses that seemed to be struggling.... but without the 'cloverleaf' levels of recognition fell even further. The use of the 'cloverleaf' created conflict in some, regarding its association with a declining co-operative movement. 
However it was also noted that even co-operative businesses operating in same sector had used different fascias. For example in food, the movement operated under the Welcome, Late Shop, and Swift banners. As the former Head of Brand noted:

'It \{the Cloverleaf\} had been altered by borders, additional wording, colour etc. We were abusing the format. The use of words such as Welcome was an attempt to soften the cloverleaf as it was seen to be weak. Within the CWS, specialist retail had moved away from it towards Funeralcare and Travelcare etc and the Co-op bank never used it.'

While these weaknesses were acknowledged, a number of reservations were still raised over the notion of single unified brand. For example, individual elements within tCG were concerned that the brand might be tarnished by other, less professional co-operative businesses and openly questioned whether it was necessary for all parts of the movement to look the same.

In contrast, smaller independent societies voiced their concerns about the loss of their local identity and the 'lack of respect' shown towards their businesses. It was feared that replacing identifiable local fascias with national corporate symbols would remove an important link to the community and as a consequence, a source of differentiation. As one independent society member noted:

'The original brand standards were far too rigid and inflexible, alienating independent societies who saw this as a subtle way of 'removing' some of their independence, by making their stores appear like clones of 'Big Brother' i.e. the Co-operative Group' 
The research revealed that progress at this stage could only be achieved through compromise. While all exterior signage and fascias were replaced in order to create a consistent master brand, the design made (modest) provision for independent co-operative societies to be able to identify their outlets. The brand identity was also applied to merchandising and promotional items in order to create visual coherence across the businesses. This covered elements such as in-store signage and decor, trolley handles, carrier bags, A-frames, POS, dump bins, ticket wallets, carrier bags and name tags.

Even after these concessions some resistance was still experienced by those who felt that the new offer represented a retrograde step in terms of standards and design. As one respondent commented:

'They \{the brand standards\} lacked any cohesion in terms of an overall store design package and were simply inferior to the design standards that were being operated by the more switched on independent societies. So why on earth would they wish to 'switch' to a poorer standard of interior design than they already had?'

What emerges from this stage of the research is that even after consultation and communication with the movement's numerous different interest groups, it was not possible to overcome all levels of resistance. Nevertheless it was recognised by the Brand Panel that a successful rebranding exercise was predicated upon the active engagement of the various stakeholder groups and the creation of mock-up stores and displays at roadshow events allowed a wide cross section of views to be considered. 


\section{Stage Four: Aligning Operations and Standards}

It was realised by the Brand Panel that a successful rebranding exercise required a holistic approach and co-operation across the movement. In particular the redesign and reformulation of the Co-operative's visual identity needed to be matched by the delivery of consistent standards in all branches and stores. To achieve this required a focus upon and, if necessary a re-alignment of, other functions and departments.

An example where re-alignment was necessary was provided by two interviewees. In a number of locations across the UK co-operative societies had traditionally competed against each other. Although part of the wider movement they had different operating procedures, merchandise layouts and loyalty schemes. As one respondent highlighted:

'.if two societies trading in the same town have identical looking shop front fascias and internal décor (to brand standard) and then adopt the same membership card, how on earth do people appreciate that the apparently 'same' membership card entitles them to a completely different level of dividend to their neighbour?'

Similarly another CEO of an independent society commented:

'If we were to adopt a national brand, with other co-operative stores near to our own showing the same fascia as ours, it would be almost impossible for our members to know where our unique offers were to be found. As it is now they can recognise our distinctive fascia and style. I can only imagine the irritation and disaffection we would engender among our members if we caused such confusion. That would be in nobody's interests. The brand could work well where one society trades in one area, e.g. the Channel Islands or if the offer is identical in each society. We have neither of these features.' 
It was further noted that this confusion could be compounded where individuals were members of both societies and, as will be illustrated later, a failure to address such strategic issues can contribute to a delay in the rebranding process.

From the beginning of the rebranding project it was recognized that a cultural as well as structural re-alignment had to occur in order to better reflect the movement's new brand values. At the branch and store level, this meant achieving standards via an agreed set of performance indicators. These were benchmarks based upon competitor research and the perceived future standards required for the businesses. The 'customer offer' and 'brand operational standards' were measured internally as part of the brand sign up agreement ${ }^{\mathrm{iii}}$ whilst 'customer experience standards' were measured by an independent mystery shopping and audit programme.

As one former Marketing Director from the movement noted:

'This was the largest rebranding programme in UK retail - a massive undertaking. It was a cultural shift. \{What was\} Often missed was the behind-the-line strategy to get the 100k staff to understand what was happening.'

To help staff engage and convey these values to customers they began to receive regular communications through a Brand Newsletter and the Co-operative membership magazine. More directly, the movement created a 'Brand Experience' training programme which was designed to communicate how important rebranding was to the Co-operative, what was involved, what were the expected behaviours and the importance of working together. In order to provide a benchmark, the engagement of colleagues was initially measured and later compared once the training had been completed and the business units rebranded. 


\section{Stage Five: Brand Pilot Tests}

Between September 2005 and September 2006, pilot tests were carried out across a group of 42 outlets using four different retail societies. The key objective of these tests was to gauge consumer understanding and recognition of the new brand and their proclivity to try the new offer. A series of key performance indicators permitted the business performance of the pilot stores to be compared against a control group of outlets. This list of measurable criteria varied across the businesses but included sales, prescription volumes and new account volumes, customer transactions, bookings and footfall as well as average basket spend.

All pilot outlets were also independently audited using mystery shoppers (this was the first time that a consistent method for measuring operational procedures had been agreed across the societies). In addition, the level of colleague engagement within the pilot units was also compared to staff in other stores across the movement.

\section{Stage Six: Assessing Brand Pilot Outcomes}

The pilots established that the commercial benefits that stemmed from rebranding varied between different business sectors with food, pharmacy and travel stores outperforming the control groups in terms of the number of customers and total transactions. Across these stores an average sales uplift of $10 \%$ over a normal refit was identified, however the trading benefits for both the Co-operative Bank and its funeral businesses were much more limited. 
The research noted two implications stemming from the pilots. First, the results were seen to be enough to create an impetus for the exercise to be continued, secondly, they helped address the concerns that some staff had about the process itself. Respondents noted that seeing positive and tangible outcomes further legitimised the rebrand and helped to allay employee fears.

Although acknowledged as crucial to the exercise, it was felt that financial measurements could not be seen as the sole determinants of success. Such a view reinforces the work of Chaudhuri (2002) who noted the positive impact that factors such as corporate reputation and engagement could have upon brand performance. The pilot research therefore examined whether the reputation of the movement had been enhanced by the rebranding exercise. Using its own Corporate Reputation Index, the pilot demonstrated that rebranding could deliver an improvement in how existing and potential customers perceived the co-operative movement. Similarly a staff 'Engagement Index' showed a higher level of colleague satisfaction in the pilot locations compared to elsewhere. Respondents in the pilot stores stated that they felt more valued, more committed and had greater pride in the business. Interestingly the Index showed improvements from both Co-operative management as well as shop floor staff.

\section{Stage Seven: Preparation for Brand Re-launch}

Following the completion of the Brand Pilot programme and an analysis of all the results, the Brand Panel recommended to the Board of Directors that a complete rebrand be undertaken across the co-operative movement. The decision to re-launch was approved by the Board in July 2006 with the first independent society, Midcounties Co-op confirming participation in September 2006. 
Similarly tCG began the process of changing all of its business units to the new brand in early 2007 with the implementation programme being intensified during 2008 and 2009. All of the Group's four and a half thousand business units were scheduled to be rebranded and refurbished by the end of 2010 (with the acquired Somerfield stores and Britannia branches following as soon as was practicable).

Despite the improved trading figures it was also noted that the Brand Pilots did not overcome the concerns of all the independent societies about a loss of their trading identity. As one Brand Panel member explained:

'We were attempting to get to a position where the independent societies would come on board but many waited for the Co-operative Group to show that the Brand was successful. The societies were being 'cautious' and were 'waiting to see how it went'. There was some suspicion and surprise at the sales uplifts that were achieved.'

As the rollout continued in 2007, other societies such as Lothian, Borders and Angus, Anglia and Radstock joined the rebranding programme. At the same time, the Scottish Midland Co-op (who had been part of the pilot) made the decision to play no further part in the re-launch. Moreover one other co-operative undermined the whole notion of a single unified brand by deciding to selectively apply elements of the new visual identity (and choosing an alternative colour scheme for its external fascia). 
Highlighting the holistic nature of the exercise, this stage of the rebranding process also saw an investment in other elements of the movement's brand identity, for example, the repackaging and re-launch of its own brand products sold through CRTG. The Brand Panel had previously identified this as an issue of importance as the presence of these products in customers' homes was central to the brand experience. Whilst it had been impossible to revitalise all of the own brand products prior to the Pilot, this activity was given priority once the launch was confirmed. As a former Head of Co-op Brand noted:

'Own brands are very important in that they 'touch' consumers more often than shops do. Plus approx. $40 \%$ of all our grocery sales are own brand. It was not possible to repackage/ rebrand these for a limited number of pilot stores but once the full roll out began a lot of effort was put behind rebranding and revitalising the Co-operative own brand range of 3,000 products. Not only has this been important in changing consumer perceptions but also played a key part in helping other societies accept the new branding (as they got these products automatically through CRTG).'

\section{Stage Eight: Brand Launch}

Initially the launch of the new Co-operative brand had been scheduled for the late Spring of 2008, however the movement faced a strategic dilemma. It could not wait until every store and outlet had been refurbished, yet at the same time a premature brand launch would have undermined the integrity of the brand itself. While all the communications were in place (including a major advertising campaign), the launch date was revised when it became apparent that less than half of the business units would have been refurbished to the required standards and the realignment of operations was not complete. As one Group Director and Brand Panel member identified: 
'The biggest issue regarding time was that brand communications were divorced from operations. We were being driven by the readiness of the advert rather than whether operations were ready to deliver... We needed to avoid the increase in uncertainty and loss of trust when you have something is promised before it can be delivered. This required the brand to be in the right position before the launch. This was a big lessonwhen operations drift away from Brand communications then you generate distrust'.

The Co-operative Group's Board of Directors took the view that a delay until the following year would result in a more significant proportion of businesses being brand compliant and would improve the likely success of the strategy.

The Brand was formally launched to the public in February 2009 with a $2 \frac{1}{2}$ minute long national TV ad featuring Bob Dylan's 'Blowin' in the Wind'. The song, chosen to associate with the ethical stance of the co-operative contrasted starkly against the price-themed advertising evident during the early phase of the global recession. As one Brand Panel member stated:

'It's not a pure commercial advert, it's talking about all the good things we do, climate change to fair-trade to community projects.'

In support of the national TV ad, an integrated communications campaign was designed to optimise the value of a $£ 10$ million television advert. This package utilised the broad range of conventional media including press, cinema and billboards, direct marketing and point of sale material in all co-operative stores and businesses as well as online and social media. Designed for broad coverage, it also targeted more specific customer groups. Pre- launch activity had generated media interest in the use of Dylan's song whilst employees and active members of the co-operative were encouraged to engage others using a viral text messaging campaign. The initial media campaign was followed up by second and third waves in June and October 2009. 


\section{Stage Nine: Post Launch Performance}

Evaluating the impact of a rebranding project across an entire movement remains complex. The on-going process of store upgrades and refits meant that the exercise could not be benchmarked against a single start date. Between 2006 and 2010 consumer co-operatives in the UK saw a $23 \%$ in sales turnover and tCG itself saw its net profits increase by $31.5 \%$ (Co-operatives UK, $2011,2010,2009,2008,2007)$. Over the same period however, the larger co-operative societies continued to dispose of unprofitable sections of their business as well as undertake a number of acquisitions. Directly attributing improvements in the financial performance of the movement to the rebrand is therefore likely to carry a significant margin of error.

Nevertheless it is noted that the brand value of The Co-operative grew from $£ 400$ million in 2007 to $£ 2.88$ billion in 2010 (Costa, 2010) and the Corporate Reputation Index showed an 11 fold increase between 2006 and 2010 (Co-operatives Group 2010a). In a review of the strongest consumer brands in the UK, it was noted that:

'Under the Masterbrand its family of businesses from food retail to financial services is experiencing a renaissance as consumers increasingly see the value in The Cooperative's integrity' (Superbrands 2009 / 10)

and

'The rebrand of the Somerfield estate and the merger of the Britannia Building Society with The Co-operative Financial Services have cemented the Co-operative as one of Britain's strongest brands' (Superbrands 2011). 
In addition, $\mathrm{tCG}$ recruited almost three-quarters of a million new members and experienced a $43 \%$ increase in the number of individuals trading with more than one of its businesses (source: Co-operative Press Release 11/09/2008; Co-operative Group, 2010b).

\section{Discussion and Conclusions}

Skålén (2009) maintained that marketing studies outside that of consumer research have lacked an empirical focus, this is despite the contribution that grounded research can make to explaining underlying structures, patterns of action and how particular outcomes are derived (see also Jarzabkowski and Spee, 2009). In the context of this research, Plewa et al (2011) noted the limited number of case studies on rebranding and the tendency to focus upon 'why' rather than 'how' rebranding occurs. This is despite the acknowledgement that a practice based approach to brand building can provide useful managerial guidance (Järventie-Thesleff et al, 2010).

This paper has attempted to partly address the gap in the literature by examining in detail the practices through which the UK co-operative movement was rebranded over a ten year period. It was guided by the work of Miller and Merrilees (2011) who identified three phases of rebranding that are underpinned by a further six principles. It will be argued in this final section that the results from this research not only provide new insights into the retail rebranding process they also help further refine this conceptual model.

Declining market share, a loss of competitiveness and the closure of numerous societies are amongst the factors that led the co-operative movement to 'Re-vision' its corporate brand (Miller and Merrilees, 2011). The challenge for the movement was to maintain their core ideology while 
at the same time progressing the brand in order for it to remain contemporarily relevant. This research highlighted a deeply held set of beliefs that are of critical importance to many cooperative members. These principles both distinguish and influence the way in which the movement operates and, while this core ideology may represent a non-negotiable set of values, this case also identified the pressure that existed to progress the brand. A dichotomy therefore exists between the brand heritage and the physical representation of the brand. While many consumers understood and identified with the key values of the movement, this was not translated into a contemporary perception of the product offer.

While it was necessary to ensure that the traditional values and principles of the movement were embedded in the new brand strategy, there appeared to be little requirement to maintain a memory that linked to previous embodiments of the brand (and in particular the Cloverleaf). While Merrilees and Miller (2008) noted the importance of sustaining a nexus between the existing and revised brand, the historical development and autonomous structure of the cooperative movement may help explain why this was considered less of a priority. Previous attempts at developing a branded house strategy (Muzellec and Lambkin 2008) had met with limited success with societies providing numerous translations and interpretations of the various logos, fascias and emblems. This lack of consistency across the movement meant that a coherent brand identity was not present and there was little impetus to carry forward the previous brand concepts.

The role of effective communications remains a consistent theme in the rebranding literature and comprises one of the primary principles under the second of Miller and Merrilees' (2011) three phases. This research illustrated that effective communications comprises a broader and more 
multifarious set of activities than previously recognised. For example, at the outset of the process the importance of independent empirical research was identified in both legitimising and directing rebranding activities. The Report of the Commission and the information gathered by the Brand Panel not only provided direction and helped reduce subjectivity, it provided the impetus for a more 'revolutionary' approach to the overall process (Muzellec and Lambkin 2006).

At the same time, Järventie-Thesleff et al, (2010) noted the problems that stemmed from a top down process of implementation and the need to engage stakeholders was shown to be a central tenent of the co-operatives strategy. While there has been an almost universal and uncritical acceptance of the need to engage in this form of 'active co-construction' when rebranding, the research identified an unintended and limiting consequence of gaining such support. Gotsi and Andriopoulos (2007) discussed the temporal dimensions of rebranding and noted how some rebranding exercises have failed due to the limited time allocated to planning the transition process. However in the case of the co-operative's rebranding exercise the need to reach agreement across the movement was identified as a key reason why it took almost ten years from conception to execution. Although a more ambitious pace could have been set, the constant need to search for agreement and reach decisions through compromise was responsible for extending the process. As a former Head of Brand noted:

'Throughout the development of the brand a significant emphasis was placed on stakeholder engagement, not least with retail co-operative societies across the UK. This was due to both the federal role/ nature of the Co-operative Group and the brand projects ultimate vision of a single consumer facing retail co-operative brand (irrespective of the number of owners/participants). Therefore an iterative approach was adopted to society engagement and consultation. This also ensured best practice was shared for the common good.' 
While Miller and Merrilees' (2011) third phase of corporate rebranding focused upon the implementation of strategy, the limited number of empirical studies that currently exist has constrained the further conceptual development of this stage in the process. The findings from this research partially rectify this by expanding upon and detailing the tasks involved. It identifies six stages involved in implementation, from aligning operational standards through to post launch evaluation. Moreover it was possible to identify rebranding activities undocumented in previous research. For example, it was noted that brand consistency could not be achieved without a formal process of 'policing' and that any re-alignment of the marketing mix needed to be accompanied by a series of measures that guarded against significant deviations from agreed standards. Given the importance assigned to human action in determining marketing outcomes, (Skålén and Hackley, 2010), the application of such centralised control measures, represents a logical, managerial initiative.

Perhaps the most significant contribution made by this case is the insight it provides into the issues of compliance across a movement of loosely linked, independent societies with multiple identities, multiple stakeholders and multiple cultures. Järventie-Thesleff et al, (2010) highlighted the complexities involved in brand alignment and noted how previous research has underestimated the strategic role employees play in interpreting and defining marketing outcomes. This would support Miller and Merrilees' (2011) contention that there is the need to fully understand how consensus is achieved when responsibility for brand ownership is shared across numerous individuals and organisations. This paper identified that achieving agreement across all parties is not only unlikely, it remains unnecessary in order for the strategy to progress. 
Although it also acknowledges that the failure of stakeholders to engage does result in a dilution of the overall impact of the rebranding strategy.

The reasons for non compliance are numerous, for example, while some societies feared a loss of 'local' identity and wished to remain independent, others maintained that the established 'brand standards' were far too rigid and inflexible and that a 'design by committee' approach had led to poor decision making. Some other societies complained of a lack of engagement, maintaining that the consultation process had been inadequate and that they had not been fully involved. As a consequence, the outcomes that were eventually derived from the rebranding exercise reflected these tensions. While some independent societies immediately engaged with the brand, others temporarily delayed the decision, selectively chose elements of the new identity or decided to take no further part. Such choices are not afforded under traditional notions of corporate rebranding. Fortunately those not wishing to be involved represented only a minority of cooperative businesses (accounting for approximately 7\% of turnover (Co-operative Review 2011)) and their ability to undermine the synergies inherent with a brand house strategy remained limited. As Aaker and Joachimsthaler, (2000) note, to fully benefit from shared associations, there is a need for a consistent visual identity and coherence across all businesses (Muzellec and Lambkin, 2009; Merrilees and Miller, 2008; Vallaster and de Chernatony, 2006).

Muzellec and Lambkin (2008) identified three levels of organisational rebranding and while many of the conditions that apply to a corporate exercise are evidenced in this case, a number of the challenges and outcomes remain unique to this type of organisational structure. On the basis of the evidence presented in this paper, it can be suggested that a fourth level of 'Federal 
Rebranding' exists where compromise and consensus are primary considerations and where, despite a prolonged period of consultation, adoption and acceptance are by no means guaranteed.

While this case has essentially focused upon the co-operative movement and the challenges involved in rebranding across a federal structure, a broader, more general series of issues may also be derived from this study. The practice orientated approach adopted by the paper allows a number of practical implications to be drawn out that may in turn provide guidance for organisations wishing to embark upon a process of corporate rebranding (Table 5). 
Table 5 Practical implications derived from the co-operative case

\begin{tabular}{|l|l|}
\hline Key Issue & Comment \\
\hline Legitimacy & $\begin{array}{l}\text { Impetus for change should be fully endorsed by senior management and } \\
\text { ideally supported by empirical evidence that highlights the need for change. }\end{array}$ \\
\hline $\begin{array}{l}\text { Clarity of Brand } \\
\text { Standards }\end{array}$ & $\begin{array}{l}\text { The Brand standards need to be clearly defined from the outset. This will } \\
\text { enable roll out, identify potential dilution and misinterpretation as well as } \\
\text { facilitate future brand extensions. }\end{array}$ \\
\hline $\begin{array}{l}\text { Timescales and } \\
\text { resources }\end{array}$ & $\begin{array}{l}\text { Realistic timescales need to be set and adhered to. A formal planning process } \\
\text { should allow the time necessary to achieve the desired cultural transformation. } \\
\text { An overly protracted process will however result in a loss of organisational } \\
\text { impetus as well as having resource implications. }\end{array}$ \\
\hline Focus & $\begin{array}{l}\text { Other strategic priorities are likely arise over the rebranding period. There is } \\
\text { a need to ensure that the process does not become sidelined and that the } \\
\text { organisation remains committed to achieving its goals even when other } \\
\text { strategic issues dominate. }\end{array}$ \\
\hline $\begin{array}{l}\text { Communication } \\
\text { and consensus }\end{array}$ & $\begin{array}{l}\text { While a clearly articulated communications strategy to all stakeholders is } \\
\text { fundamental, gaining complete consensus across all parties is both unlikely } \\
\text { and unnecessary. }\end{array}$ \\
\hline Brand Launch & $\begin{array}{l}\text { In the case of large multiple retailers, it is not necessary to have the entire } \\
\text { store portfolio rebranded prior to the launch. However continual delays in any } \\
\text { refurbishment programme will ultimately impact upon the integrity of the new } \\
\text { brand identity. }\end{array}$ \\
\hline Policing & $\begin{array}{l}\text { While a successful rebranding strategy requires an investment in training and } \\
\text { the communication of new standard operating procedures (SOPs) to all staff, } \\
\text { this needs to be accompanied by a system of policing, monitoring and } \\
\text { evaluation. }\end{array}$ \\
\hline
\end{tabular}


Finally, this case study has served to highlight the numerous gaps that continue to remain in our conceptual and practical understanding of the rebranding process. At a strategic level, the extent to which other organisations experience stages and timelines similar to the co-operative movement remains uncertain. Moreover, given the holistic nature of corporate rebranding and its emphasis upon interdisciplinary, cross functional co-operation, further research may be undertaken into the actual management process. For example, how conflict is resolved and the means by which consensus is achieved may serve to inform marketing theory as well as provide practical managerial guidance.

In conclusion therefore, the case evidence from this paper has both reinforced elements of the existing rebranding literature as well as further contributed to the theoretical debate. The positive trading performance of the rebranded stores together with research commissioned by the Cooperative Group confirmed that the new brand had been well received by both customers and employees. Such changes may well result in confirmation of a statement by Co-operative Group Chief Executive, Peter Marks (2009), 'we are witnessing a renaissance of the Co-operative.' 


\section{References}

Aaker, D. (1996), "Building Strong Brands”, New York, Free Press.

Aaker, D. and E. Joachimsthaler (2000), "The Brand Relationship Spectrum: The Key

to the Brand Architecture Challenge", California Management Review, 42(4): 8-23.

Ahrens, T. and J. Dent (1998), "Accounting and organizations: realizing the richness of field research", Journal of Management Accounting Research, 10:1-39.

Balmer, J. and E. Gray. (2003), "Corporate Brands: What are They? What of Them?", European Journal of Marketing, 37(7/8): 972-978.

Birchall, J. (2000), "Some Theoretical and Practical Implications of the Attempted Takeover of a Consumer Co-operative Society", Annals of Public \& Cooperative Economics, 71(1): 29 - 54.

Brownlie, D.,and Saren, M. (1997), "Beyond the one-dimensional marketing manager: the discourse of theory, practice and relevance", International Journal of Research in Marketing, 14 (2), pp.147-61.

Chaudhuri, A. (2002), "How brand reputation affects the advertising-brand equity link", Journal of Advertising Research, 42( 3): 33-43.

Co-operative Commission (2001), "The Co-operative Advantage. Creating a successful family of Co-operative businesses", London, The Co-operative Commission.

Co-operative Group (2011), "The Co-operative Group. Building a better society”. Annual Report \& Accounts 2010, Manchester, The Co-operative Group.

Co-operative Group (2010a), “Join the Revolution, Sustainability Report 2010”, Manchester, The Co-operative Group.

Co-operative Group (2010b), "What is a Co-operative?" Available at: http://www.cooperative.coop/aboutus/thecooperativemovement/ (Last accessed 17th November 2010).

Co-operative Press Release (11/9/08), "The Co-operative reaches re-brand milestone", Available at http://www.co-operative.coop/corporate/Press/Press-releases/Headline-news/The-Cooperative-reaches-re-brand-milestone/ (Last accessed 17th November 2010).

Co-operatives UK (2011), “The UK co-operative economy. Britain's return to co-operation 2011”, Manchester, Co-operatives UK.

Co-operatives UK (2010), "The UK co-operative economy. A review of co-operative enterprise 2010", Manchester, Co-operatives UK.

Co-operatives UK (2009), “The Co-operative Review”, Manchester, Co-operatives UK. 
Co-operatives UK (2008), “The Co-operative Review”, Manchester, Co-operatives UK.

Co-operatives UK (2007), “The Co-operative Review”, Manchester, Co-operatives UK.

Costa, M. (2010), “The Top 50 British Brands”, Marketing Week, 29/07/2010:14-18.

Davies, K. and Burt, S. (2007), “Consumer co-operatives and retail internationalisation: problems and prospects", International Journal of Retail \& Distribution Management 35 (2), pp. 156-177

Davis, P. and Worthington, S. (1993), "Co-operative values: change and continuity in capital accumulation. The case of the British Cooperative Bank", Journal of Business Ethics, 12, pp. 849-59.

De Chernatony, L. and F. Riley (1998), "Modelling the components of the brand", European Journal of Marketing, 32(11/12):1074-90.

Dias, S. and L. Ryals, (2002), "Options theory and options thinking in valuing returns on brand investments and brand extensions”, Journal of Product \& Brand Management, 11( 2 ):115-128.

Eisenhardt, K. M. (1989), "Building theories from case studies research", Academy of Management Review, 14: 532-550.

Gotsi, M. and C. Andriopoulos, C. (2007), "Understanding the pitfalls in the corporate rebranding process", Corporate Communications:An International Journal, 12(4): 341 - 355.

Gotsi, M., C. Andriopoulos, and A. Wilson (2008), "Corporate re-branding: is cultural alignment the weakest link?" Management Decision, 46(1): 46 - 57.

Hankinson, G. (2009), "Managing destination brands: establishing a theoretical foundation", Journal of Marketing Management, 25:1-2, 97-115

Harris, F. and L de Chernatony (2001), "Corporate branding and corporate brand performance", European Journal of Marketing, 35(3/4): 441-456.

Hallsworth, A. and J. Bell (2003), "Retail change and the United Kingdom Co-operative Movement - new opportunity beckoning?", The International Review of Retail, Distribution and Consumer Research, 13(3): 301-315.

Hatch, M., and M. Schultz (2003), "Bringing the corporation into corporate branding", European Journal of Marketing, 37(7/8):1041 - 1063.

Hongwei, H. and Y Baruch (2010), "Organizational Identity and Legitimacy under Major Environmental Changes: Tales of Two UK Building Societies”, British Journal of Management, 21:44-62. 
Hooley, G., G. Greenley, J. Cadogan, and J. Fahy (2005), “The performance impact of marketing resources", Journal of Business Research, 58(1):18-27.

Hsieh, H-F. and Shannon, S. (2005) "Three Approaches to Qualitative Content Analysis", Qualitative Health Research, 15 (9) 1277-1288.

Järventie-Thesleff, R., Moisander, J. and Laine, P. (2010), “Organizational dynamics and complexities of corporate brand building - A practice perspective", Scandinavian Journal of Management, 27 pp.196 - 204.

Jarzabkowski, P. and Spee, A. (2009), "Strategy-as-practice: A review and future directions for the field”, International Journal of Management Reviews 11 (1) pp. 69-95.

Kaikati, J. (2003), "Lessons from Accenture's 3Rs: rebranding, restructuring and repositioning", Journal of Product and Brand Management, 12(7): 477-90.

Kapferer, J-N. (1997), "Strategic Brand Management: Creating and Sustaining Brand Equity Long Term”, London, Kogan Page.

Lambkin, M. and L. Muzellec (2008), "Rebranding in the banking industry following mergers and acquisitions", International Journal of Bank Marketing, 26(5): 328-352.

Lambkin, M. and L. Muzellec (2011), "Leveraging brand equity in business-to-business mergers and acquisitions", Industrial Marketing Management 39 (8) pp.1234-1239.

Lindebaum, D. and C. Cassell (2012), "A Contradiction in Terms? Making Sense of Emotional Intelligence in a Construction Management Environment”. British Journal of Management, 23 (1) pp.65-79.

Marks, P. (2009), "Co-op to close down Somerfield HQ” . Available at: http://news.bbc.co.uk/1/hi/business/7892625.stm, (Accessed 26 October, 2010).

Merrilees, B. and D. Miller (2008), "Principles of corporate rebranding”, European Journal of Marketing, 42(5/6): 537-552.

Miller, D. and Merrilees, B. (2011), "Corporate Rebranding” in Burke, R., Martin, G. and Cooper, C. (eds) Corporate Reputation: Managing Opportunities and Threats, pp. 281-305, London, Gower.

Murphy, C. (2004), “The two faces of the Co-op”', Marketing, 09/02/2004 pp.28-30.

Muzellec, L. and M. Lambkin (2009), "Corporate branding and brand architecture: a conceptual framework”, Marketing Theory, 9(1): 39-54.

Muzellec, L. and Lambkin, M. (2008), "Corporate Rebranding and the Implications for Brand Architecture Management: The Case of Guinness (Diageo) Ireland", Journal of Strategic Marketing, 16(4): 283-99. 
Muzellec, L. and Lambkin, M. (2006), "Corporate rebranding: destroying, transferring or creating brand equity?", European Journal of Marketing, 40(7/8): 803-824.

Palmer, M. (2004), "International Retail Restructuring and Divestment: The Experience of Tesco", Journal of Marketing Management, 20, 1075-1105

Parker, L. (2008), "Boardroom Operational and Financial Control: an Insider View", British Journal of Management, 19: 65-88.

Plewa, C., Lu, V. and Veale, R. (2011), "The impact of rebranding on club member relationships", Asia Pacific Journal of Marketing and Logistics, 23 (2), pp.222 - 242.

Provera, B., A. Montefusco, and A. Canato (2010), “A 'No Blame' Approach to Organizational Learning”. British Journal of Management, 21: 1057-1074. doi: 10.1111/j.14678551.2008.00599.x

Quinn, J. and L. Sparks (2007), "The Evolution of Grocery Wholesaling and Grocery Wholesalers in Ireland and Britain since the 1930s", International Review of Retail, Distribution and Consumer Research,17( 4): 3911 - 411.

Skålén, P and Hackley, C (2010), "Marketing-as-practice. Introduction to the special issue", Scandinavian Journal of Management, 27 pp.189-195.

Skålén, P. (2009), "Service marketing and subjectivity: the shaping of customer-oriented employees”, Journal of Marketing Management, 25 (7-8) pp. 795-809.

Sparks, L. (1994), "Consumer co-operation in the UK 1945 - 1993: review and prospects", Journal of Co-operative Studies,79: 1- 64.

Strauss, A. and J. Corbin (1998), "Basics of Qualitative Research: Techniques and Procedures for Developing Grounded Theory" 2nd edn. Thousand Oaks, CA: Sage.

Stuart, H. (2011), "An identity-based approach to the sustainable corporate brand", Corporate Communications: An International Journal, 16 (2), pp.139 - 149.

Stuart, H. and L. Muzellec, (2004), “Corporate makeovers: can a hyena be rebranded?", Journal of Brand Management, 11(6): 472-82.

Superbrands (2009 / 10), "Superbrands Annual: An insight into some of Britain's strongest brands", Superbrands UK, London.

Superbrands (2011), “Superbrands Annual 2011: An insight into some of Britain's strongest brands", Superbrands UK, London.

Svensson, P. (2007), "Producing marketing: towards a social-phenomenology of marketing work" Marketing Theory 7 (3) pp. 271-290 
Tesch, R. (1990) Qualitative research: Analysis types and software tools. Bristol, PA: Falmer.

Urde, M. (1999), "Brand orientation: a mindset for building brands into strategic resources", Journal of Marketing Management, 15(1-3): 117-33.

Vallaster, C. and L. de Chernatony, (2006), "Internal brand building and structuration: the role of leadership", European Journal of Marketing, 40(7/8): 761-784.

Walter, G. (2010), "Make promises you can keep (integrated design success)", Design Management Review, Vol. 21 No.1, pp.14-23.

Walton, J. (2009), “The post-war decline of the British retail Co-operative movement: nature, causes and consequences", in Black, L and Robertson, N. (Eds), Consumerism and the Cooperative movement in modern British history: Taking stock, Manchester, Manchester University Press.

\footnotetext{
${ }^{\mathrm{i}}$ A co-operative is defined as a group of people acting together to meet the common needs and aspirations of its members, sharing ownership and making decisions democratically (Co-operative Group 2010a).

${ }^{\text {ii }}$ A full description of these Principles may be found at: http://www.uk.coop/economy/values

iii Only stores who had passed both forms of audit could 'sign up' for the new brand identity.
} 